Web Jurnal:

http://ejournal.kemenperin.go.id/jli

\title{
Perlakuan ozon dan sonokimia untuk degradasi residu mankozeb pada cabe hijau (Capsicum annuum L.)
}

\section{Ozone and sonochemical treatment for mancozeb residues degradation on green chilies (Capsicum annuum L.)}

\author{
Safni Safni*1, Elma Fadrita Rahman', Deswati Deswati ${ }^{1}$, Salmariza $\mathbf{S y}^{2}$ \\ 1 Laboratorium Kimia Analisis Terapan, Jurusan Kimia FMIPA, Universitas Andalas \\ Limau Manis, Padang, Sumatera Barat, Indonesia \\ 2 Baristand Industri Padang, J1. Raya LIK No. 23 Ulu Gadut, Padang, Sumatera Barat, Indonesia \\ * e-mail: safni@sci.unand.ac.id
}

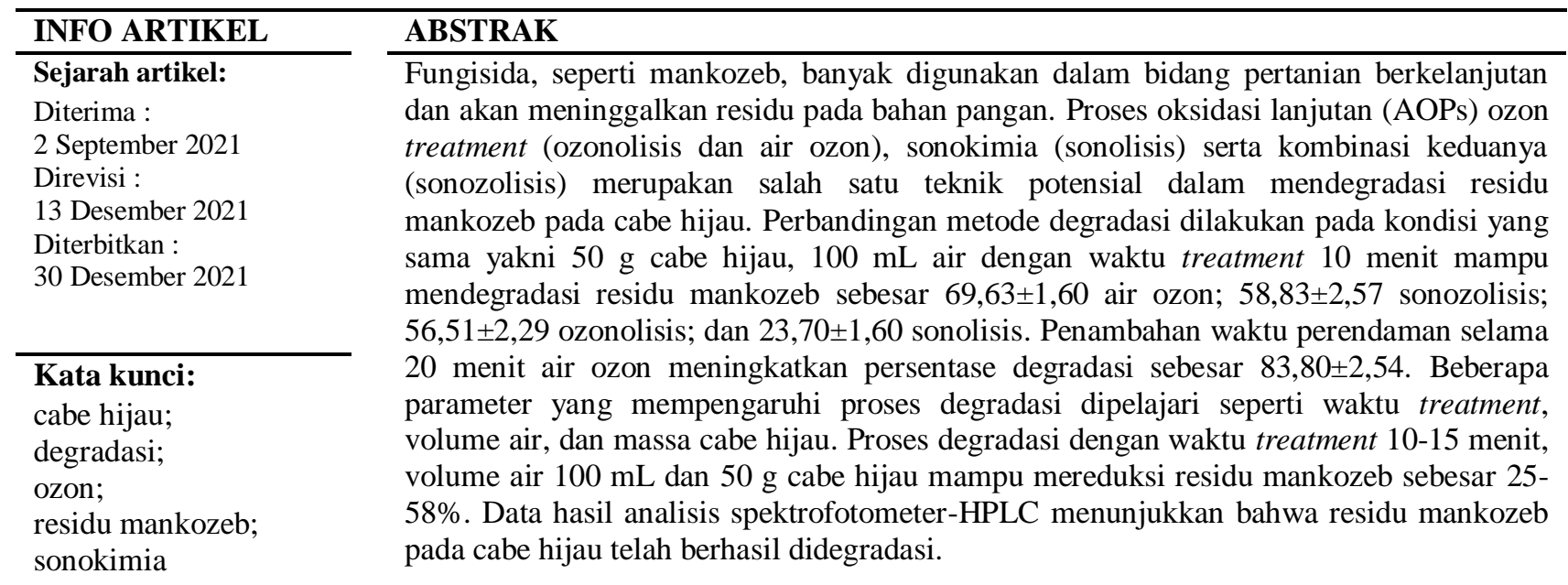

\footnotetext{
Keywords: green chilies; degradation; ozon; mancozeb residue; sonochemical
}

\begin{abstract}
Fungicides, such as mancozeb, are widely used in sustainable agriculture and will leave residues on food. Advanced oxidation processes (AOPs) include ozone treatment (ozonolysis and water ozone), sonochemistry (sonolysis), and their combination (sonozolysis) as potential techniques for degradation of mancozeb residues in green chilies. Comparison of the degradation methods carried out under the same conditions, $50 \mathrm{~g}$ of green chilies, $100 \mathrm{~mL}$ of water with 10 minutes of degradation time was able to degrade mancozeb residue by $69.63 \pm 1.60$ ozonated water; $58.83 \pm 2.57$ sonozolysis; $56.51 \pm 2.29$ ozonolysis; and $23.70 \pm 1.60$ sonolysis. The addition of soaking time for 20 minutes of ozonated water increased the percentage of degradation by $83.80 \pm 2.54$. Several parameters that affect the degradation process were studied, such as treatment time, volume of water, and mass of green chilies. The degradation process with treatment time is 10-15 minutes, $100 \mathrm{~mL}$ of water and $50 \mathrm{~g}$ of green chilies can reduce mancozeb residue by 25-58\%. Data from the spectrophotometer-HPLC analysis showed that the mancozeb residue in green chilies had been successfully degraded.
\end{abstract}




\section{Pendahuluan}

Cabe hijau (Capsicum annuum L.) merupakan jenis sayuran yang banyak ditanam dan dimanfaatkan dalam industri pangan dan ada yang menyebutnya sebagai obat dengan kandungan utama minyak atsiri dan piperin. Indonesia beriklim tropis menjadi kendala utama budidaya cabe hijau dengan meningkatnya pertumbuhan jamur pada musim hujan. Penggunaan fungisida berkelanjutan akan meningkatkan hasil produksi cabe serta keuntungan ekonomi bagi petani. Oleh karena itu, penggunaan fungisida dalam jumlah besar secara teratur mengurangi penyakit yang disebabkan oleh jamur dan hama. Namun, aplikasi fungisida yang berlebihan mengakibatkan residu pada cabe pada setiap interval panen. Menurut Standar Nasional Indonesia (SNI), mankozeb terdaftar digunakan untuk cabe dengan kadar residu maksimum $1 \mathrm{mg} / \mathrm{kg}$.

Mankozeb termasuk fungisida non-sistemik dari kelompok ethylene bisdithiocarbamate dithiocarbamate digunakan untuk menghambat pertumbuhan jamur dengan melapisi enzim dan logam. Paparan mankozeb berpotensi teratogenik, karsinogenik, mutagenik bagi hewan dan manusia, dan termasuk dalam kelompok III (Saravi and Shokrzadeh, 2016; Bianchi et al., 2020). Saat ini metode fisiokimia proses oksidasi lanjutan (AOPs) berdasarkan produksi dan penggunaan radikal hidroksil $(\bullet \mathrm{OH})$ sebagai metode alternatif sangat menjanjikan untuk mengoksidasi residu pestisida (Deng and Zhao, 2015; Saleh et al., 2020). Proses produksi radikal hidroksil ini meliputi treatment ozon dan sonokimia (Ibrahim and Şolpan, 2020).

Treatment ozon dan sonokimia adalah teknik kimia ramah lingkungan yang dapat mendegradasi kontaminan organik tanpa mentransfer kontaminan dari satu fase ke fase lainnya. Treatment ozon (metode ozonolisis dan air ozon) dengan memanfaatkan gas ozon, begitupun treatment sonokimia (metode sonolisis) dengan memanfaatkan getaran ultrasonik yang mana kedua treatment ini sama-sama menghasilkan spesi radikal hidroksil untuk mendegradasi residu fungisida. Seringkali sonokimia diusulkan dalam kombinasi dengan teknik lain seperti metode sonozolisis menggabungkan treatment gas ozon dan getaran ultrasonik secara bersamaan untuk meningkatkan efisiensi degradasi (Gligorovski et al., 2015). Berbagai penelitian tentang penerapan AOPs terhadap degradasi pestisida dan residu pestisida telah dilaporkan (Amelia et al., 2015; Heleno et al., 2016; Arfi et al., 2017; Tzortzakis and Chrysargyris, 2017; Cengiz et al., 2018; Zhu et al., 2019; Khoiriah et al., 2020; Khoiriah et al., 2020a; Khoiriah et al., 2020b) telah disajikan sebagai metode yang efektif untuk mengubah polutan yang tidak dapat terurai menjadi zat yang tidak berbahaya.

Sepanjang studi literatur, belum ada laporan mengenai degradasi residu mankozeb pada cabe hijau menggunakan metode treatment ozon dan sonokimia. Tujuan utama penelitian ini adalah membandingkan dan mengevaluasi metode treatment ozon dan sonokimia dalam mengurangi residu mankozeb pada cabe hijau. Parameter yang mempengaruhi proses degradasi juga dipelajari, seperti waktu treatment, volume air, dan massa cabe hijau.

\section{Metode}

Bahan yang digunakan dalam penelitian ini adalah cabe hijau (Capsicum annuum L.); mankozeb 80\% (diproduksi PT. Kayaku Petrokimia); akuades; asetonitril (HPLC grade). Peralatan yang digunakan adalah reaktor ozonizer, sonikator, spektrofotometer Ultraviolet-Visible (Shimadzu Corp, serial A116352, Japan), neraca analitik, High Performance Liquid Chromatography (Agilent Technologies 1200), Whatman filter ( $\Theta: 0.22 \mu \mathrm{m})$, lumpang alu dan peralatan gelas.

\subsection{Persiapan sampel}

Cabe hijau diperoleh dari petani di Aia Angek Padang Panjang, Kabupaten Tanah Datar, Sumatera Barat dari penanaman benih hingga panen menggunakan fungisida mankozeb $80 \%$. Setelah panen, cabe hijau disimpan dalam wadah tertutup, kemudian dipotong kecil-kecil dan dihomogenkan sebelum dianalisis.

\subsection{Metode treatment ozon dan sonokimia dalam degradasi residu mankozeb pada cabe hijau}

Degradasi residu mankozeb pada cabe hijau menggunakan metode treatment ozon (ozonolisis, air ozon) dan sonokimia (sonolisis) serta gabungan keduanya (sonozolisis). Perlakuan masing-masing metode degradasi residu mankozeb dilakukan dalam kondisi yang sama. Cabe hijau sebanyak 50 g dimasukkan ke dalam gelas piala kemudian ditambahkan $100 \mathrm{~mL}$ air pada setiap percobaan perlakuan dengan waktu proses degradasi 10 menit.

- Metode ozonolisis: campuran diberikan aliran gas ozon dari reaktor ozonizer selama 10 menit.

- Metode sonolisis: campuran disonikasi dengan memberikan getaran ultrasonik pada frekuensi $40 \mathrm{kHz}$ selama 10 menit.

- Metode sonozolisis: campuran diberi aliran gas ozon dari reaktor ozonizer dan getaran ultrasonik pada frekuensi $40 \mathrm{kHz}$ secara bersamaan selama 10 menit.

- Metode air ozon: $100 \mathrm{ml}$ air dimasukkan ke dalam gelas piala kemudian ditambahkan aliran gas ozon selama 10 menit. Cabe hijau $50 \mathrm{~g}$ direndam pada air yang telah diozon selama 10 menit.

Setelah dilakukan treatment untuk masing-masing metode, cabe hijau dihaluskan dan ditambahkan $100 \mathrm{~mL}$ air untuk memisahkan filtrat dan disaring dengan kertas saring Whatman $0,22 \mu \mathrm{m}$. Larutan dianalisis dengan spektrofotometer UV-Vis pada panjang gelombang 286 nm.

\subsection{Metode treatment perendaman dengan air ozon}

$100 \mathrm{~mL}$ air dimasukkan ke dalam gelas piala kemudian diberi aliran gas ozon dari reaktor ozonizer selama 10 menit tanpa sampel. $50 \mathrm{~g}$ cabe hijau masingmasing direndam dalam air ozon dengan memvariasikan waktu perendaman yaitu $5,10,15,20$, dan 25 menit. Setelah dilakukan treatment, cabe hijau dihaluskan dan ditambahkan $100 \mathrm{~mL}$ air untuk memisahkan filtrat dan disaring dengan kertas saring Whatman 0,22 $\mu \mathrm{m}$. Larutan dianalisis dengan spektrofotometer UV-Vis pada 
panjang gelombang $286 \mathrm{~nm}$.

\subsection{Parameter degradasi residu mankozeb pada cabe hijau}

Parameter degradasi residu mankozeb pada cabe hijau yang diteliti dalam penelitian ini adalah pengaruh waktu treatment, volume air, dan massa cabe hijau. Degradasi residu mankozeb pada cabe hijau dilakukan melalui dua metode, yaitu memanfaatkan gas ozon dari reaktor ozonizer dan getaran ultrasonik. Cabe hijau sebanyak $50 \mathrm{~g}$ dimasukkan ke dalam gelas piala kemudian ditambahkan $100 \mathrm{~mL}$ air. Metode treatment dengan ozon pada campuran diberi aliran gas ozon, serta metode sonokimia campuran diberi getaran ultrasonik dengan waktu proses degradasi masing-masing $(5,10$, 15, 20, dan 25) menit untuk mempelajari pengaruh waktu degradasi. Setelah metode treatment, cabe hijau dihaluskan dan ditambahkan $100 \mathrm{~mL}$ air, disaring menggunakan kertas saring Whatman 0,22 $\mu \mathrm{m}$ untuk memisahkan filtrat. Larutan dianalisis dengan spektrofotometer UV-Vis pada panjang gelombang 286 $\mathrm{nm}$. Pengaruh volume air dipelajari dengan cabe hijau sebanyak $50 \mathrm{~g}$ dimasukkan ke dalam gelas piala dengan memvariasikan volume air $(50,100,150$, dan 200) $\mathrm{mL}$ dan didegradasi selama 10 menit. Pengaruh pertambahan massa cabe hijau dipelajari dengan variasi $25 \mathrm{~g}, 50 \mathrm{~g}, 75$ $\mathrm{g}$, dan $100 \mathrm{~g}$. Sampel kontrol dilakukan dengan prosedur yang sama tanpa treatment.

Persentase degradasi residu mankozeb dihitung dari data spektrofotometri menggunakan persamaan (1). Dimana $\mathrm{C}_{0}$ dan $\mathrm{C}_{\mathrm{t}}$ merupakan konsentrasi awal dan akhir dari degradasi residu mankozeb pada cabe hijau. Analisis data penelitian ini diulang tiga kali dan dianalisis menggunakan program Microsoft Excel (Microsoft Inc. USA). Nilai dinyatakan dalam mean \pm standar deviasi (SD).

$$
\text { Persentase degradasi }=\frac{\mathrm{C}_{0}-\mathrm{C}_{\mathrm{t}}}{\mathrm{C}_{0}} \times 100 \%
$$

\subsection{Analisis HPLC}

Larutan mankozeb dan larutan residu mankozeb sebelum dan sesudah degradasi dianalisis menggunakan High-Performance Liquid Chromatography (HPLC) dengan detektor UV pada panjang gelombang $286 \mathrm{~nm}$. HPLC dilengkapi dengan kolom C18 (150 mm × 4,6 $\mathrm{mm})$. Fasa gerak yang digunakan adalah campuran asetonitril:air (50:50 v/v), laju alir 0,7 mL/menit, dan volume injeksi $10 \mu \mathrm{L}$.

\section{Hasil dan Pembahasan \\ 3.1. Perbandingan metode treatment degradasi residu mankozeb pada cabe hijau}

Degradasi residu mankozeb pada cabe hijau dipelajari dengan menggunakan metode treatment ozon (ozonolisis, air ozon), sonokimia (sonolisis), dan kombinasi keduanya (sonozolisis) bertujuan untuk melihat penurunan konsentrasi fungisida. Proses oksidasi lanjutan secara kimia dapat bekerja melalui ozonasi (oksidasi langsung atau tidak langsung oleh gas ozon) serta memanfaatkan energi ultrasonik. Kedua proses tersebut secara signifikan mengurangi kadar residu pestisida dengan menghasilkan spesies aktif seperti radikal hidroksil untuk memecah molekul organik dan residu fungisida pada sayuran (Chen et al., 2013; Fitriadi and Putri, 2016). Penelitian menggunakan radikal hidroksil sebelumnya telah diselidiki dalam degradasi larutan pestisida maupun residu pestisida dalam buahbuahan dan sayuran sebagai alternatif aman yang menjanjikan (Heshmati and Nazemi, 2018; Rodrigues et al., 2019; Chanrattanayothin et al., 2020; Pandiselvam et al., 2020; Wang et al., 2021).

Degradasi residu mankozeb pada cabe hijau dengan metode treatment ozon dan sonokimia ditunjukkan pada Gambar 1. Metode degradasi pada penelitian ini diperlakukan pada kondisi yang sama yaitu $50 \mathrm{~g}$ cabe hijau, volume air yang digunakan $100 \mathrm{~mL}$ dan waktu proses degradasi adalah 10 menit. Persentase degradasi residu mankozeb pada cabe hijau masing-masing metode treatment adalah 56,51 $\pm 2,29$ ozonolisis; $69,63 \pm 1,60$ air ozon; 23,70 $\pm 1,60$ sonolisis, dan $58,83 \pm 2,57$ sonozolisis. Berdasarkan hasil penelitian pada Gambar 1, metode air ozon mendegradasi residu mankozeb pada cabe hijau lebih baik dibandingkan metode lainnya, terbukti dengan persentase hasil degradasi yang paling tinggi.

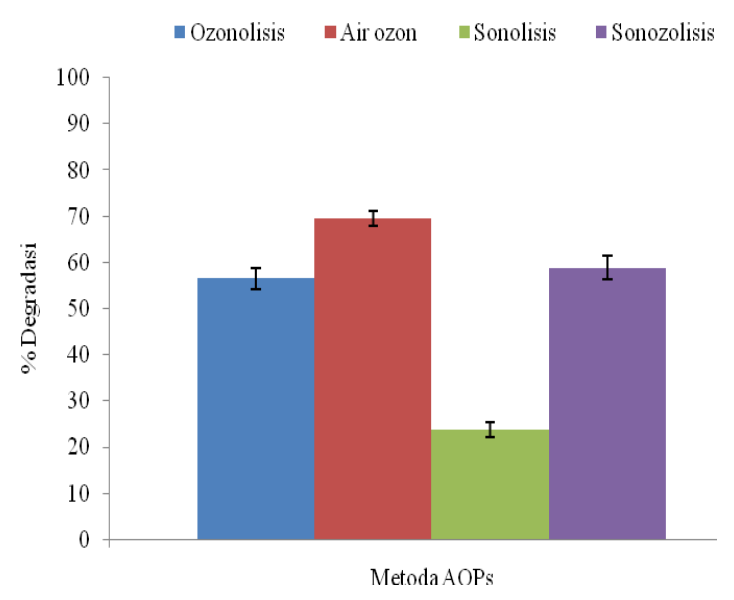

Gambar 1. Pengaruh metode AOPs terhadap degradasi residu mankozeb pada cabe hijau

Pembentukan radikal hidroksil menggunakan metode air ozon lebih efektif karena gas $\mathrm{O}_{3}$ dialirkan langsung ke dalam air tanpa adanya sampel untuk menghasilkan spesies yang lebih aktif. Berbeda dengan metode ozonolisis, aliran gas ozon dilakukan bersamaan dengan cabai hijau dan ditambahkan air. Kehadiran sampel dalam proses ozonolisis mempengaruhi produksi dan kinerja radikal hidroksil akan terhambat. Pembentukan radikal akan lebih banyak bila kontak langsung dengan air, namun perlakuan ozonolisis dapat melalui oksidasi langsung oleh ozon yang menempel pada permukaan jaringan epidermis cabai hijau dan secara tidak langsung dari pembentukan radikal bebas. Secara umum proses penguraian ozon di dalam air (Ibrahim and Şolpan, 2020) melalui persamaan (2).

$$
\mathrm{O}_{\mathrm{a}}+\mathrm{H}_{2} \mathrm{O} \rightarrow 2^{\mathrm{O} O H}+\mathrm{O}_{2}
$$


Proses sonolisis memanfaatkan getaran ultrasonik melalui uap dan gas terlarut yang terperangkap dalam larutan dengan adanya gelembung kavitasi. Efek kavitasi ini menyebabkan gelembung-gelembung dalam larutan tumbuh, mengembang, dan akhirnya pecah membentuk gelombang kejut yang tersebar di pori-pori permukaan cabai hijau (Lozowicka et al., 2016). Seringkali, ultrasonik digabungkan dengan gas ozon untuk memberikan tingkat oksidasi yang lebih tinggi dari generasi radikal hidroksil yang dihasilkan dari runtuhnya gelembung kavitasi gabungan dan dekomposisi ozon. Kombinasi sonikasi ozon $\left(\mathrm{US} / \mathrm{O}_{3}\right)$ dilaporkan lebih efektif dalam degradasi pestisida daripada getaran ultrasonik saja (US) (Pirsaheb and Moradi, 2020).

Reaksi dalam proses sonolisis ditunjukkan pada persamaan (3). Reaksi gabungan dari ozon dan getaran ultrasonik ditunjukkan pada persamaan (4) dan (5).

$$
\begin{aligned}
& \left.\left.\mathrm{H}_{2} \mathrm{O}+()\right)\right) \rightarrow{ }^{\circ} \mathrm{OH}+\mathrm{H}^{\prime} \\
& \left.\left.\left.\mathrm{O}_{3}+\right)\right)\right) \rightarrow \mathrm{O}_{2}+\mathrm{O}(\mathrm{P}) \\
& \mathrm{O}(\mathrm{P})+\mathrm{H}_{2} \mathrm{O} \rightarrow 2 \mathrm{OH}
\end{aligned}
$$

\subsection{Pengaruh metode treatment perendaman dengan air ozon terhadap degradasi residu mankozeb pada cabe hijau}

Metode treatment air ozon pada degradasi residu mankozeb sebelumnya memiliki persentase degradasi tertinggi, oleh karena itu penelitian dilanjutkan dengan memvariasikan waktu perendaman yaitu 5, 10, 15, 20, dan 25 menit. Gambar 2 menunjukkan peningkatan persentase degradasi residu mankozeb dengan bertambahnya waktu perendaman. Lama perendaman berkisar 5-20 menit, residu mankozeb pada cabe hijau terdegradasi sebesar $64,12 \pm 2,91$ dan meningkat menjadi $83,80 \pm 2,54$.

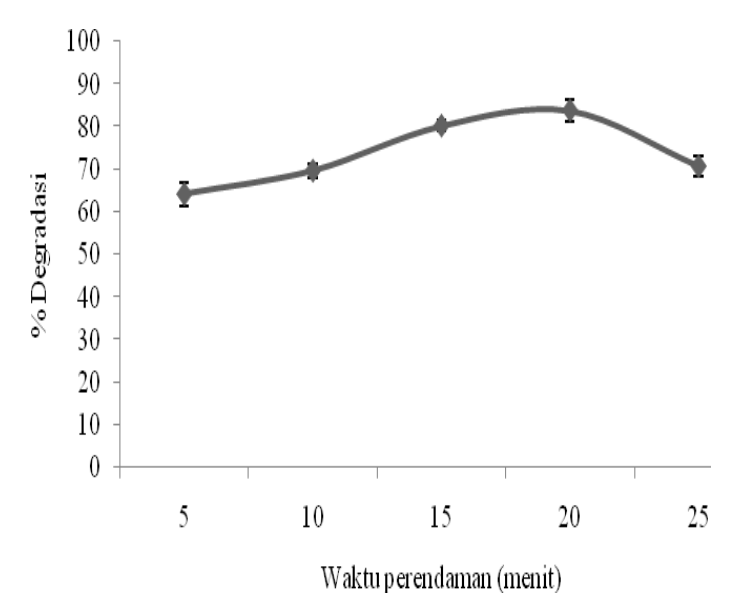

Gambar 2. Pengaruh perendaman air ozon terhadap degradasi residu mankozeb pada cabe hijau

Air yang diozonisasi dapat mengurangi konsentrasi residu fungisida dengan menggunakan radikal hidroksil untuk memutuskan ikatan senyawa organik seperti $=\mathrm{S}$,
-SH, -OH, -NH, $\mathrm{Mn}^{2+}, \mathrm{Zn}^{2+}, \mathrm{Fe}^{2+}$, dan zat anorganik lainnya (Wang et al., 2019). Kemampuan ozon untuk mengoksidasi senyawa organik dalam fase gas atau larutan berair secara langsung atau tidak langsung melalui dua jalur oksidasi (Safni et al., 2015; Wang et al., 2019; Pandiselvam et al., 2020). Lebih banyak radikal hidroksil terbentuk dalam perlakuan perendaman air ozon karena gas ozon berinteraksi dengan air untuk membentuk spesies radikal bebas, diikuti oleh reaksi oksidan ini dengan polutan organik. Reduksi ozon terlarut dimungkinkan untuk lebih efektif memutuskan ikatan senyawa organik (Azam et al., 2020). Selain mensterilkan, penggunaan ozon memperpanjang umur simpan produk makanan dengan menghambat pertumbuhan jamur, memungkinkannya untuk disimpan lebih lama.

\subsection{Pengaruh waktu treatment terhadap degradasi residu mankozeb pada cabe hijau}

Pengaruh waktu treatment terhadap degradasi residu mankozeb pada cabe hijau ditunjukkan pada Gambar 3. Proses degradasi dievakuasi melalui dua proses yang berbeda, yaitu mengalirkan gas ozon ke dalam wadah berisi sampel yang telah direndam dengan air (ozonolisis) dan memberikan getaran ultrasonik dengan frekuensi $40 \mathrm{kHz}$ (sonolisis). Secara keseluruhan dari Gambar 3, siklus grafik menurun bahkan dengan bertambahnya waktu treatment menunjukkan penurunan persentase degradasi. Peningkatan persentase terjadi pada rentang waktu treatment degradasi 5-15 menit. Dengan waktu 10 menit, residu mankozeb pada cabe hijau terdegradasi sebesar 57,77 $\pm 2,91$ secara ozonolisis, dan 15 menit dengan sonolisis terdegradasi sebesar $25,82 \pm 2,57$.

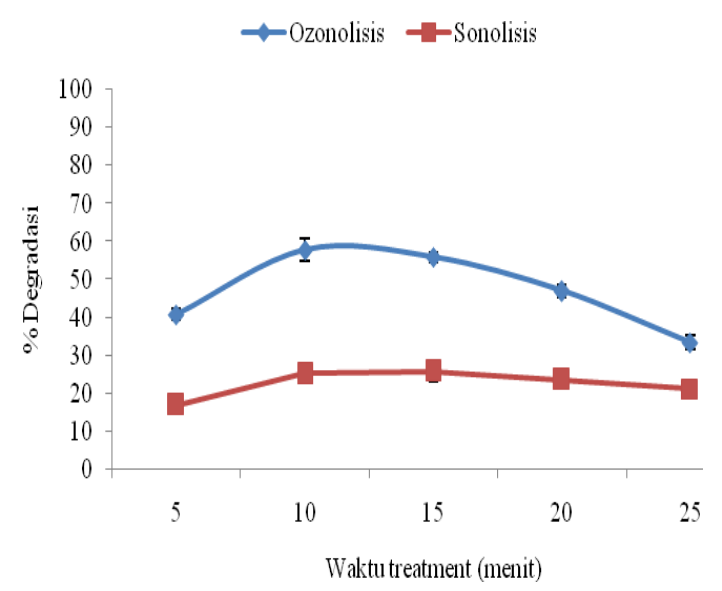

Gambar 3. Pengaruh waktu treatment terhadap degradasi residu mankozeb pada cabe hijau

Metode degradasi dapat mengurangi residu fungisida pada sayuran walaupun dengan waktu proses yang lebih cepat. Penguraian gas ozon dan gelembung kavitasi sonokimia meningkatkan pembentukan radikal hidroksil, keduanya membutuhkan air sebagai pelarut (Safni et al., 2015; Savi et al., 2016; Stefan, 2019). Dalam waktu treatment kurang dari 20 menit, Ikeura et al (2013) melaporkan pengurangan $32-52 \%$ residu fenitrothion 
dalam selada dan tomat ceri. Dari hasil penelitian degradasi residu mankozeb pada cabe hijau memperoleh waktu treatment yang jauh lebih cepat dengan persentase degradasi lebih besar.

\subsection{Pengaruh volume air terhadap degradasi residu mankozeb pada cabe hijau}

Pengaruh volume air terhadap persentase degradasi residu mankozeb pada cabe hijau ditunjukkan pada Gambar 4. Persentase degradasi adalah 57,77 $\pm 2,91$ ozonolisis dan 27,72 $\pm 2,23$ sonolisis secara berurutan meningkat dengan penambahan volume air hingga 100 $\mathrm{mL}$. Penurunan persentase degradasi terjadi setelah penambahan volume air. Hal ini disebabkan penggunaan air yang melebihi batas optimum menyebabkan proses degradasi menjadi berkurang. Radikal hidroksil akan kembali menjadi oksigen di dalam air menyebabkan kinerja radikal hidroksil mengalami penurunan dalam mereduksi kontaminan (Gligorovski et al., 2015).

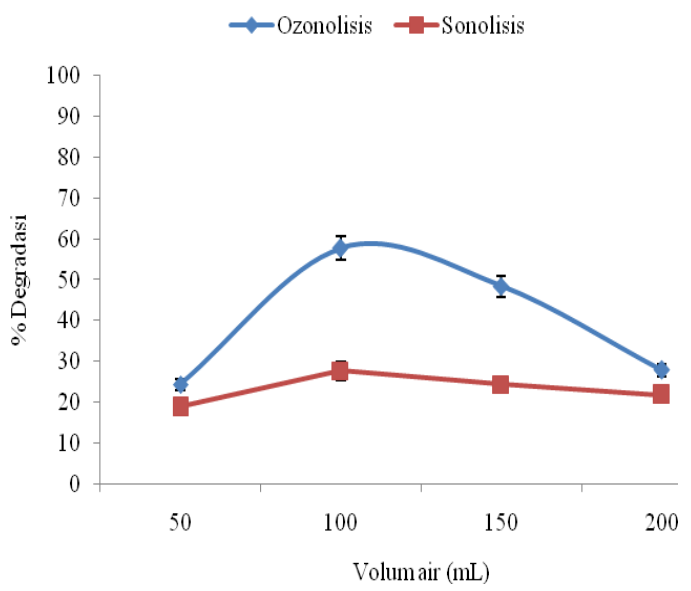

Gambar 4. Pengaruh volume air terhadap degradasi residu mankozeb pada cabe hijau

Studi ini menunjukkan bahwa air dalam metode treatment ozon dan sonokimia memainkan peran sangat penting. Hal ini juga mengindikasikan pembentukkan radikal hidroksil. Radikal hidroksil $(\mathrm{E}=2.8 \mathrm{~V})$ memiliki selektivitas rendah dan mudah dihasilkan dalam larutan berair. Interaksi radikal hidroksil dengan senyawa organik didasarkan pada penambahan elektron pada ikatan rangkap atau abstraksi hidrogen. Radikal hidroksil ini dapat menghancurkan sebagian besar ikatan dalam proses oksidasi berbagai senyawa.

\subsection{Pengaruh massa cabe hijau terhadap degradasi residu mankozeb}

Degradasi residu mankozeb pada cabe hijau dievaluasi dengan memvariasikan massa cabe hijau 25, 50, 75, dan 100 g. Gambar 5 menunjukkan persentase degradasi meningkat dengan penambahan massa cabe hijau hingga 50 g. Residu mankozeb dalam cabe hijau dapat didegradasi sebesar 58,41 $\pm 1,91$ oleh ozonolisis dan 26,03 $\pm 2,29$ oleh sonolisis. Penambahan massa cabe hijau mengurangi persentase degradasi secara signifikan. Hal ini disebabkan turbiditas larutan massa cabe yang besar mengalami penurunan persentase degradasi karena rasio molar fungisida menurunkan konsentrasi ozon terlarut dan terhalangnya getaran ultrasonik dalam pembentukan radikal hidroksil karena kandungan residu yang lebih besar dalam larutan (Putri et al., 2019; Khoiriah et al., 2019).

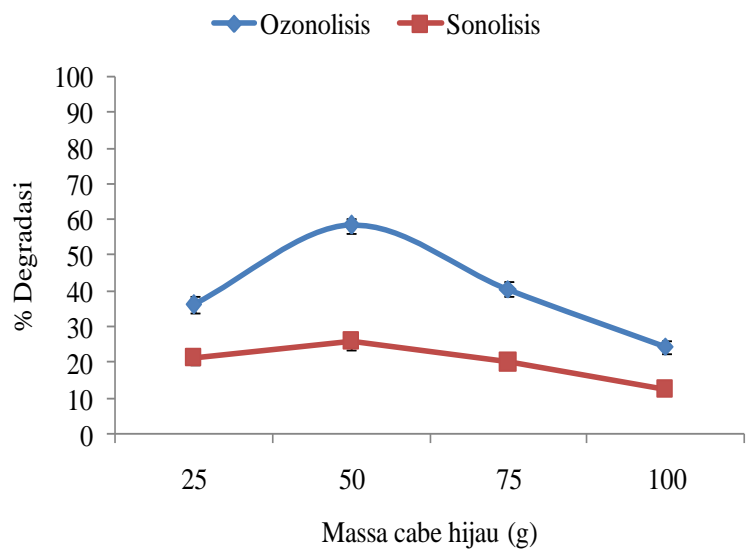

Gambar 5. Pengaruh massa cabe hijau terhadap degradasi residu mankozeb

\subsection{Analisis HPLC}

Gambar 6 menunjukkan kromatogram larutan mankozeb, residu mankozeb pada cabe hijau sebelum dan sesudah degradasi. Puncak mankozeb muncul pada waktu retensi 8.146 menit. Intensitas puncak kromatogram residu mankozeb sebelum dan sesudah degradasi menurun dari 283 menjadi 81. Gambar 6 menyimpulkan bahwa metode air ozon dapat mendegradasi residu fungisida sehingga dapat diartikan bahwa konsentrasi fungisida yang terkandung dalam sayuran mengalami penurunan. Berdasarkan data pengukuran kualitatif sebelum dan sesudah dilakukan treatment tidak ada puncak baru yang terbentuk setelah degradasi residu mankozeb pada cabe hijau. Hal ini juga sejalan dengan perolehan data spektrofotometer, nilai absorbansi setelah degradasi lebih kecil dibandingkan sebelum degradasi.

Penentuan kadar residu mankozeb berdasarkan ambang batas maksimum pada cabe hijau perlu diperhatikan. Hal ini untuk memastikan validasi metode degradasi yang tepat dan dapat digunakan dalam mereduksi residu fungisida. Menurut SNI 2007 mengenai batas maksimum residu mankozeb pada cabe hijau adalah $1 \mathrm{mg} / \mathrm{kg}$. Konsentrasi mankozeb setelah didegradasi dengan perendaman air ozon adalah 0,83 $\mathrm{mg} / \mathrm{kg}$.

Hal menarik lainnya terkait matriks cabe hijau seperti jaringan pericarp dan sarcocarp akan mempengaruhi proses degradasi residu (Ikeura et al., 2013). Cabe hijau memiliki pericarp kulit luar yang sangat tebal dengan struktur yang lebih keras. Radikal hidroksil bekerja lebih dominan pada perikarp dibandingkan pada sarkokarp. Ini memungkinkan kontak ozon terlarut dalam air secara efektif menurunkan lebih banyak residu fungisida pada jaringan pericarp. Ikeura et al (2013) menyatakan bahwa jaringan sarkokarp kaya akan antioksidan seperti vitamin A dan $\mathrm{C}$ yang bermanfaat bagi manusia. Oleh karena itu, proses degradasi yang melibatkan radikal hidroksil 
mampu menurunkan konsentrasi residu fungisida, selain itu tidak merusak antioksidan yang terkandung dalam

cabe hijau setelah dilakukannya treatment.

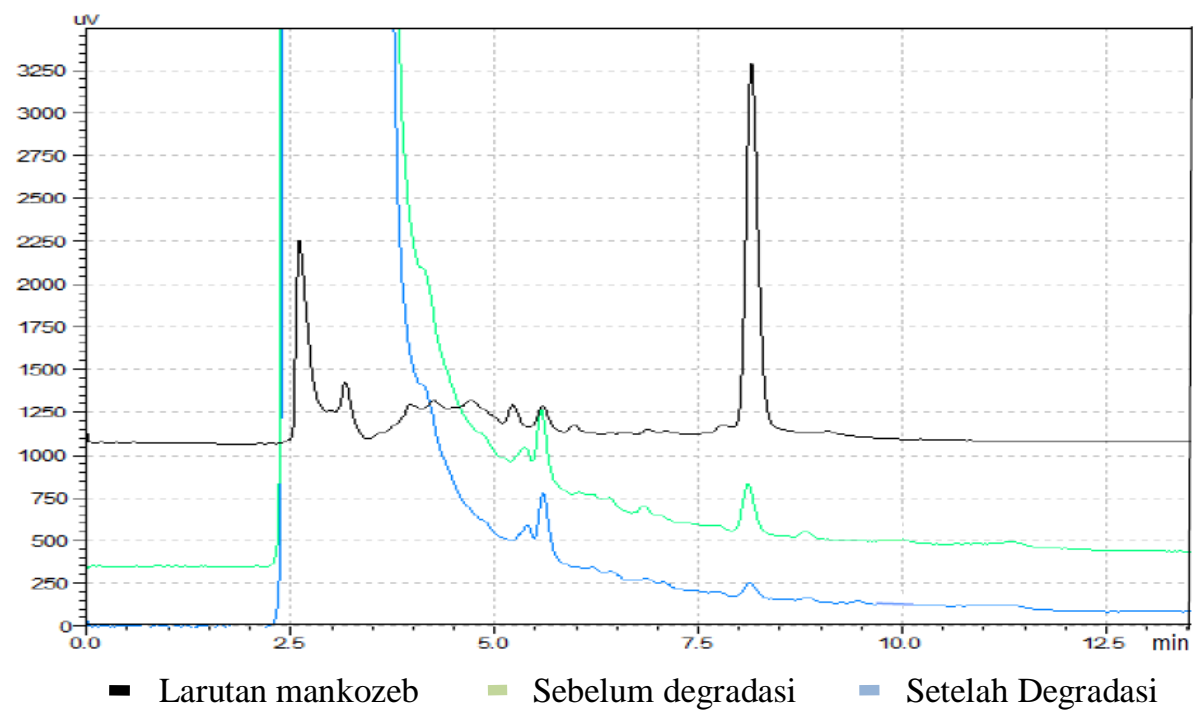

Gambar 6. Analisis HPLC residu mancozeb pada cabe hijau

\section{Kesimpulan}

Residu mankozeb pada cabe hijau telah berhasil didegradasi dengan membandingkan perlakuan ozon (ozonolisis dan air ozonasi) dan sonokimia (sonolisis) serta kombinasi keduanya (sonozolisis). Residu mankozeb terdegradasi paling tinggi pada proses perendaman air ozon dengan persentase degradasi 69$83 \%$ pada waktu treatment degradasi $\sim 20$ menit. Degradasi residu mankozeb sangat dipengaruhi oleh waktu treatment, volume air, dan massa cabe hijau. Hasil analisis HPLC menunjukkan bahwa residu mankozeb pada cabe hijau berhasil didegradasi ditunjukkan dengan penurunan puncak kromoatogram dan konsentrasi mankozeb setelah didegradasi.

\section{Daftar Pustaka}

Amelia, F., Safni, Suyani, H., 2015. Degradasi senyawa imidakloprid secara advanced oxidation processes dengan penambahan $\mathrm{TiO}_{2}$-Anatase. J. Ris. Kim. 8, 108. https://doi.org/10.25077/jrk.v8i2.225

Arfi, F., Safni, S., Abdullah, Z., 2017. Degradation of paraquat in gramoxone pesticide with addition of ZnO. Molekul 12, 159. https://doi.org/10.20884/ 1.jm.2017.12.2.326

Azam, S.M.R., Ma, H., Xu, B., Devi, S., Bakar, A., Stanley, S.L., Bhandari, B., Zhu, J., 2020. Efficacy of ultrasound treatment in the and removal of pesticide residues from fresh vegetables: A review. Trends Food Sci. Technol. 97, 417-432. https://doi.org/ 10.1016/j.tifs.2020.01.028

Bianchi, S., Nottola, S.A., Torge, D., Palmerini, M.G., Necozione, S., Macchiarelli, G., 2020. Association between female reproductive health and mancozeb: Systematic review of experimental models. Int. J. Environ. Res. Public Health 17. https://doi.org/ 10.3390/ijerph17072580

Cengiz, M.F., Başlar, M., Basançelebi, O., Kılıçlı, M., 2018. Reduction of pesticide residues from tomatoes by low intensity electrical current and ultrasound applications. Food Chem. 267, 60-66. https://doi.org/10.1016/j.foodchem.2017.08.031

Chanrattanayothin, P., Peng-Ont, D., Masa-Ad, A., Warisson, T., Nirunsin, R., Sintuya, H., 2020. Degradation of cypermethrin and dicofol pesticides residue in dried basil leave by gaseous ozone fumigation. Ozone Sci. Eng. 42, 469-476. https://doi.org/10.1080/01919512.2019.1708699

Chen, J.Y., Lin, Y.J., Kuo, W.C., 2013. Pesticide residue removal from vegetables by ozonation. J. Food Eng. 114, 404-411. https://doi.org/10.1016/j.jfoodeng. 2012.08.033

Deng, Y., Zhao, R., 2015. Advanced Oxidation Processes (AOPs) in wastewater treatment. Curr. Pollut. Reports 1, 167-176. https://doi.org/ 10.1007/s40726-015-0015-Z

Fitriadi, B.R., Putri, A.C., 2016. Metode-metode pengurangan residu pestisida pada hasil pertanian. J. Rekayasa Kim. Lingkung. 11, 61. https://doi.org/10.23955/rkl.v11i2.4950

Gligorovski, S., Strekowski, R., Barbati, S., Vione, D., 2015. Environmental implications of hydroxyl radicals $(\cdot \mathrm{OH})$. Chem. Rev. 115, 13051-13092. https://doi.org/10.1021/cr500310b

Heleno, F.F., De Queiroz, M.E.L.R., Faroni, L.R.A., Neves, A.A., De Oliveira, A.F., Costa, L.P.L., Pimenta, G.G., 2016. Aqueous ozone solutions for pesticide removal from potatoes. Food Sci. Technol. Int. 22, 752-758. https://doi.org/10.1177/ 1082013216651179

Heshmati, A., Nazemi, F., 2018. Dichlorvos (DDVP) residue removal from tomato by washing with tap and ozone water, a commercial detergent solution and ultrasonic cleaner. Food Sci. Technol. 38, 441446. https://doi.org/10.1590/1678-457x.07617

Ibrahim, K.E.A., Şolpan, D., 2020. Removal of carbaryl pesticide in aqueous solution by UV and UV/hydrogen peroxide processes. Int. J. Environ. Anal. Chem. 00, 1-15. https://doi.org/10.1080/ 
03067319.2020.1767091

Ikeura, H., Kobayashi, F., Tamaki, M., 2013. Ozone microbubble treatment at various water temperatures for the removal of residual pesticides with negligible effects on the physical properties of lettuce and cherry tomatoes. J. Food Sci. 78, T350-T355. https://doi.org/10.1111/1750-3841.12007

Khoiriah, K., Safni, S., Syukri, S., Gunlazuardi, J., 2020a. Photocatalytic ozonation using C,N-Codoped $\mathrm{TiO}_{2}$ for diazinon degradation. J. Chem. Technol. Metall. 55, 2120-2127.

Khoiriah, K., Safni, S., Syukri, S., Gunlazuardi, J., 2020. The operational parameters effect on photocatalytic degradation of diazinon using carbon and nitrogen modified $\mathrm{TiO}_{2}$. Rasayan J. Chem. 13, 1919-1925. https://doi.org/10.31788/RJC.2020.1335743

Khoiriah, K., Wellia, D.V., Gunlazuardi, J., Safni, S., 2020b. Photocatalytic degradation of commercial diazinon pesticide using $\mathrm{C}, \mathrm{N}$-codoped $\mathrm{TiO}_{2}$ as photocatalyst. Indones. J. Chem. 20, 587. https://doi.org/10.22146/ijc.43982

Khoiriah, K., Wellia, D.V., Safni, S., 2019. Degradasi pestisida diazinon dengan proses fotokatalisis sinar matahari menggunakan katalis $\mathrm{C}, \mathrm{N}-$ Codoped $\mathrm{TiO}_{2}$. J. Kim. dan Kemasan 41, 17. https://doi.org/ 10.24817/jkk.v41i1.3834

Lozowicka, B., Jankowska, M., Hrynko, I., Kaczynski, P., 2016. Removal of 16 pesticide residues from strawberries by washing with tap and ozone water, ultrasonic cleaning and boiling. Environ. Monit. Assess. 188, 51. https://doi.org/10.1007/s10661-0154850-6

Pandiselvam, R., Kaavya, R., Jayanath, Y., Veenuttranon, K., Lueprasitsakul, P., Divya, V., Kothakota, A., Ramesh, S. V, 2020. Ozone as a novel emerging technology for the dissipation of pesticide residues in foods-a review. Trends Food Sci. Technol. https://doi.org/10.1016/j.tifs.2019.12.017

Pirsaheb, M., Moradi, N., 2020. Sonochemical degradation of pesticides in aqueous solution: Investigation on the influence of operating parameters and degradation pathway-a systematic review. RSC Adv. 10, 7396-7423. https://doi.org/ 10.1039/c9ra11025a

Putri, R.A., Safni, S., Wellia, D.V., Septiani, U., Jamarun, N., 2019. Degradasi zat warna orange-F3R dan Violet-3B secara sonolisis frekuensi rendah dengan penambahan katalis C-N-Codoped $\mathrm{TiO}_{2}$. J. Kim. Val. 5, 35-43. https://doi.org/10.15408/ jkv.v5i1.7801
Rodrigues, A.A.Z., Queiroz, M.E.L.R. de, Neves, A.A., Oliveira, A.F. de, Prates, L.H.F., Freitas, J.F. de, Heleno, F.F., Faroni, L.R.D.A., 2019. Use of ozone and detergent for removal of pesticides and improving storage quality of tomato. Food Res. Int. 125, 108626. https://doi.org/10.1016/j.foodres. 2019.108626

Safni, S., Anggraini, D., Wellia, D., Khoiriah, K., 2015. Degradation of direct red-23 and direct violet dyes by ozonolysis and photolysis methods with UV light and solar irradiation using $\mathrm{N}$-Doped $\mathrm{TiO}_{2}$ catalyst. J. Litbang Ind. 5, 123-130.

Saleh, I.A., Zouari, N., Al-Ghouti, M.A., 2020. Removal of pesticides from water and wastewater: Chemical, physical and biological treatment approaches. Environ. Technol. Innov. 19, 101026. https://doi.org/10.1016/j.eti.2020.101026

Saravi, S., Shokrzadeh, M., 2016. Effects of washing, peeling, storage, and fermentation on residue contents of carbaryl and mancozeb in cucumbers grown in greenhouses. Toxicol. Ind. Health 32, 1135-1142. 0748233714552295

Savi, G.D., Piacentini, K.C., Bortolotto, T., Scussel, V.M., 2016. Degradation of bifenthrin and pirimiphos-methyl residues in stored wheat grains ( Triticum aestivum L.) by ozonation. Food Chem. 203, 246-251. https://doi.org/10.1016/j.foodchem. 2016.02.069

Stefan, M.I., 2019. Advanced oxidation processes for water treatment. IWA Publishing, London SW1H OQS, UK.

Tzortzakis, N., Chrysargyris, A., 2017. Postharvest ozone application for the preservation of fruits and vegetables. Food Rev. Int. 33, 270-315. https://doi.org/10.1080/87559129.2016.1175015

Wang, S., Wang, J., Li, C., Xu, Y., Wu, Z., 2021. Ozone treatment pak choi for the removal of malathion and carbosulfan pesticide residues. Food Chem. 337, 127755. https://doi.org/10.1016/j.foodchem.2020. 127755

Wang, S., Wang, J., Wang, T., Li, C., Wu, Z., 2019. Effects of ozone treatment on pesticide residues in food: a review. Int. J. Food Sci. Technol. 54, 301312. https://doi.org/10.1111/ijfs. 13938

Zhu, Y., Zhang, T., Xu, D., Wang, S., Yuan, Y., He, S., Cao, Y., 2019. The removal of pesticide residues from pakchoi (Brassica rape L. ssp. chinensis) by ultrasonic treatment. Food Control 95, 176-180. https://doi.org/10.1016/j.foodcont.2018.07.039 